\title{
Kaupunkitutkimus siivitti Helsingin kansainvälistymistä
}

\author{
Eero Holstila
}

Helsinki oli vuonna 1990 Neuvostoliiton kainalossa lymynneen aika eristäytyneen Suomen pääkaupunki, jossa vain yksi prosentti asukkaista oli ulkomaalaisia. Osuus lienee ollut tuolloin Euroopan alhaisin. Oli eletty Suomen kansaintalouden kukoistusta. 1980-luvun lopulla saavutimme Ruotsin ja meistä puhuttiin Euroopan Japanina.

Neuvostoliiton romahdus ja Suomen syöksy syvään lamaan muuttivat kaiken. Helsingin päättäjät joutuivat huomaamaan, ettei kansallisvaltion pääkaupunkiasema ole enää menestyksen tae yhdentyvässä Euroopassa, johon Suomikin oli liittymässä. Havaittiin, että kaupunki tarvitsee kokonaan uuden suunnan ja suunnitelman. Tässä tilanteessa ulkomailla profiloituneen kaupunkitutkijan Anne Hailan ajatuksille oli kysyntää.

Helsinki panosti muutoinkin kaupunkitutkimukseen ja tuolloin johtamani Helsingin kaupungin tietokeskus sai ison roolin kaupungin strategian uudistamisessa. Epäviralliset keskustelut Jan Verwijnenin, Anne Hailan ja Charles Landryn kanssa antoivat itselleni kokonaan uuden tulokulman Helsingin tulevaisuuteen. Syvimmän laman aikaan perustimme Maija Berndtsonin ja Kaarin Taipaleen kanssa "toivon strategiaa" kaupungille muotoilevan tulevaisuusklubin, joka huipentui vuoden 1994 maaliskuussa Finlandia-talolla pidettyyn konferenssiin. Tilaisuuden keskeiset puheenvuorot kirjattiin tietokeskuksen julkaisuun Kaupunki käännekohdassa.

Samoihin aikoihin tietokeskuksen sarjassa ilmestynyt Anne Hailan teos "Kansainvälistyvä kaupunki" kuvaa mainiolla tavalla kaupunkikehittämisen paradigman muutosta, joka Helsingissä huipentui kaupunginvaltuuston vuoden 
1994 lopulla hyväksymään kansainvälistymisstrategiaan. Kysymyksessä oli merkittävä käänne: Kaupunki ei olekaan vain paikallisia asioita varten vaan sen on kaikessa toiminnassaan otettava ympäröivä maailma huomioon. Pelkästään sopeutuminen maailman muutoksiin ei riitä, vaan kaupungin on itse rakennettava oma menestyksensä globaalissa kontekstissa.

Viitaten aikakauden johtaviin kaupunkitutkijoihin Anne Haila esittelee kirjassaan idean kansainvälisen kaupungin toimintastrategiasta. Se haastaa keskusjohtoisen kokonaisvaltaisen kaupunkisuunnittelun, joka on perusajatukseltaan determinististä eli ottaa ympäröivän maailman annettuna. Sen vastakohtana on valtiovallasta riippumattomampi yrittäjyyskaupunki (entrepreneurial city), jolla on oma ulkopolitiikka ja jonka tärkein ohjauskeino on kaupunkistrategia.

Keskeinen ajatus oli, että kaupungilla voi olla isokin liikkumavara, jota sen on kyettävä omalla politiikallaan hyödyntämään. Tätä Haila kutsuu kaupunkipolitiikaksi. Kansainvälistyvän kaupungin strategian keskeisiä elementtejä ovat yksityisen ja julkisen sektorin yhteistyö, strategisten liittoutumien rakentaminen sekä paikallisella että kansainvälisellä tasolla, ja gateway-aseman hyväksikäyttö.

Jälkeenpäin tarkasteltuna Helsingin vuoden 1994 kansainvälistymisstrategian ydinsisältö oli kovasti sukua Anne Hailan ajattelulle. Strategian kolme keskeisintä pilaria olivat innovatiivinen tiedekaupunki, kulttuuri kaupungin kilpailuvalttina sekä oma ulkopolitiikka, joka tähtää johtoasemiin eurooppalaisissa kaupunkiverkostoissa. Ensimmäistä toteutettiin kolmikantaiseen kumppanuuteen rakentuvassa yliopistojen vetämässä osaamiskeskusyhtiössä Culminatumissa. Toinen pilari tarkoitti kilvoittelua Euroopan kulttuuripääkaupungin asemasta, joka toteutui vuonna 200o. Kolmas konkretisoitui aktiivisuutena sadan Euroopan suurimman kaupungin Eurocities -järjestössä, jonka puheenjohtajaksi Helsinki valittiin sitkeän vaalikamppailun tuloksena Leipzigissa syksyllä vuonna 200o. Gateway-aseman hyödyntäminen uuden Venäjän ja yhdentyvän Länsi-Euroopan välillä oli yksi kaupungin ulkopolitiikan kulmakivistä.

Anne Haila viittaa kirjassaan useaan otteeseen Pittsbughissa 1993 pidettyyn konferenssiin, jossa joukko maailman johtavia kaupunkitutkijoita esiintyi. Nyt jälkeenpäin on hauska havaita, että monet itselleni tuolloin tuiki tuntemattomat konferenssin puhujat tulivat sittemmin tutuiksi ja myös suomalaisen kaupunkipolitiikan keskeisiksi taustavaikuttajiksi. Näistä mainittakoon erityisesti Michael Parkinson ja Leo van den Berg, joka olivat myös keskeisiä kirjoittajia EU:n kaupunkipolitiikan asiakirjassa (1998). Viimemainitun teos "Metropolitan Organizing Capacity" (1997) tarjosi viitekehyksen, johon Suomessa omaksuttu 
yliopistojen, kaupunkien ja elinkeinoelämän yhteistyöhön perustuva osaamiskeskusohjelma voitiin asettaa.

Anne Haila esitteli kirjassaan raikkaita uusia ideoita kaupunkipolitiikkaan, mutta hyvän tutkijan tapaan hän myös kyseenalaisti ne. Hän toi hyvin esiin mm. yrittäjyyskaupungin käsitteen historian 1960-luvulta ja yrittäjyysvetoisen kaupunkikehityksen vaarat demokratian kannalta.

Annen kritiikki ei estänyt meitä Helsingin strategian valmistelijoita innolla tarttumasta hänen esittelemiinsä kaupunkipoliittisiin ideoihin. Saattaapa olla, että juuri hänen antamansa inspiraatio vaikutti ratkaisevasti koko loppuelämääni. Siirryin vuonna 2001 tiedonmuodostuksen areenalta tietokeskuksesta kaupunkipoliittisen tahdonmuodostuksen puolelle Culminatumin toimitusjohtajaksi Otaniemen Innopoliin. Sitä seurasi pesti Helsingin elinkeinojohtajaksi vuodesta 2006. Samaan ketjuun voi liittää kaupungin elinvoiman käsitteen lanseerauksen Kuntaliitossa 2012 (Kaupunki oman onnensa seppänä) ja samalla Anne Hailan avaamalla polulla liikkuu vielä äskettäin ilmestynyt teoksemme "Kaupunkipolitiikan uusi aika".

Vuonna 1998 sain olla mukana valmistelemassa Helsingin kaupungin, Helsingin yliopiston ja opetusministeriön yhteishanketta viiden kaupunkitutkimuksen professuurin perustamiseksi Helsingin yliopistoon. Vuonna 2000 Anne Haila nimitettiin yhteen näistä professuureista. Oli ilo saada seurata hänen loistavaa yliopistouraansa, joka huipentui 2019 akatemiaprofessuuriin.

KIRJALLISUUS

European Commission (1998). Sustainable Urban Development in the EU. A Framework for Action. Haila, A. (1994). Kansainvälistyvä kaupunki. Helsingin kaupungin tietokeskuksen tutkimuksia 1994:5. Holstila, E. (2012). Kaupunki oman onnensa seppänä. Suomen kuntaliitto.

Holstila E. \& Hämäläinen T (toim.) (2019). Kaupunkipolitiikan uusi aika. Rakennustieto. Taipale K. ja Viertola V. (toim.) (1994). Kaupunki käännekohdassa. Helsingin kaupungin tietokeskus. Van den Berg, L, Braun, E \& van der Meer, J. (1997). Metropolitan Organising Capacity (1997). Aldershot, Ashgate Publishing. 